\title{
Estimation of Leg Magnetic Fluxes of Transformers Having a Function of DC Reactor for DC-DC Converters
}

\author{
H. Saotome, Y. Wakatsuki, T. Saito, T. Yukawa*, H. Watanabe*, H. Unno*, and Y. Kikuchi* \\ Faculty of Engineering, Chiba University, 1-33 Yayoi-cho, Inage-ku, Chiba 263-8522, Japan \\ *Shindengen Electric Mfg Co., Ltd., 10-13, Minami-cho, Hanno-shi, Saitama 357-8585, Japan
}

\begin{abstract}
Efficiency improvement and cost reduction are important requirements for the design of DC-DC converters. Zero voltage switching is one good solution for increasing efficiency, and an active clamp circuit is useful for implementing it effectively. A cost reduction could be achieved by devising a new transformer that functions not only as a conventional transformer but also as a DC reactor that reduces the switching device peak current. However, no design methodology for such a transformer has yet been established. This paper proposes a novel method that simulates the operations of a DC-DC converter and estimates the magnetic flux distribution in the new transformer. The magnetic circuit of the transformer is transformed into its equivalent electric circuit with two ideal transformers. Circuit simulation results agree fairly well with experimental ones.
\end{abstract}

Key words: transformer, DC-DC converter, circuit simulation, active clamp, zero voltage switching

\section{直流平滑リアクトル機能付 DC-DC コンバータ用トランスの脚磁束解析}

早乙女英夫 ・若月嘉真・齋藤正・湯川格* ・渡辺晴夫*・海野洋*・菊地芳彦*

千葉大学工学部, 千葉市稲毛区弥生町 1-33 (

*新電元工業株式会社，埼玉県飯能市南町 10-13（率357-8585）

\section{1. 緒 言}

家電機器の電源として適用される DC-DC コンバータには, 他の 用途の電源回路に比較してよりいっそう厳しい低コス卜要求があ り，その上で高効率変換器の実現が求められている. アクティブ クランプ回路を利用したZVS（Zero Voltage Switching）は，スイッ チング素子数を最少とする中で変換器効率を向上させる最も有効 な手段の一つである，また，部品点数の削減要求の中で，直流平 滑リアクトル (DCL) 機能をトランス本体に持たせた電源回路が 提案されている1). しかしながら，この新型トランスの設計を行う 際に必要な各脚の磁束を見積る手段が現状では得られておらず,

このトランスおよびこれを適用した DC-DC コンバータの最適設 計法が確立されていない.これは，このトランス内にはDCL 機能 による直流磁束が発生しており，これを含めたトランス内磁束分 布の解明ができていないためであり，そのため，例えば各脚の磁 路断面寸法の最適設計が行えないという課題がある. 装置の小型 化および部品点数やコスト削減要求から，この新型トランスの設 計法の確立は極めて重要な課題となっている.

本論文では, 直流平滑リアクトルレス DC-DC コンバータ用トラ ンスの設計に寄与す心゙く，このトランスの脚磁束分布の解析法を 提案し, その有効性を実機による試験結果との比較により明らか にする.

\section{2. 試作 DC-DC コンバータ}

\section{1 回路動作の概要}

試作したアクティブクランプ付 DC-DC コンバータの基本回路 を Fig.1 に示す. FET の $\mathrm{Q}_{1}$ および $\mathrm{Q}_{2}$ に交互にオンゲート信号を与 えることがこの回路への基本操作であり，ゲート信号を遮断した $\mathrm{Q}_{1}$ および $\mathrm{Q}_{2}$ のオフ時にそれぞれ $\mathrm{Q}_{2}$ および $\mathrm{Q}_{1}$ の逆並列接続ダイオ ードがオンする. $\mathrm{Q}_{1}$ のオン期間中はダイオード $\mathrm{D}_{1}$ がオンしてフオ ワードコンバータとして働き, 直流入力電圧 $V_{\mathrm{i}}$ からの電力を平滑

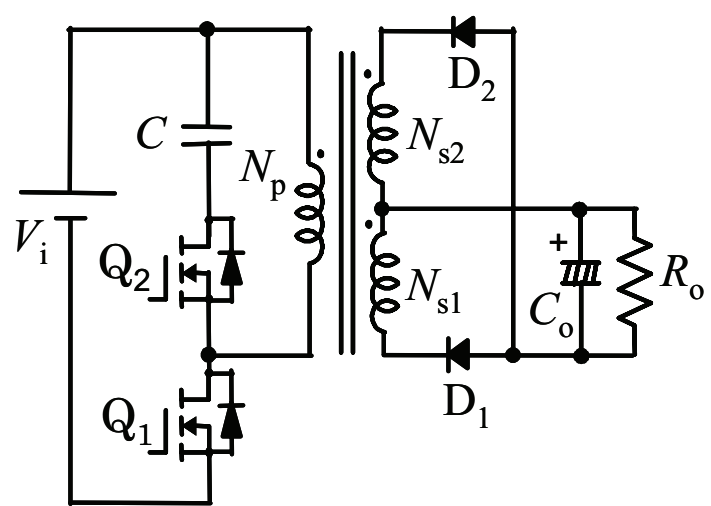

Fig. 1 ZVS DC-DC converter.

コンデンサ $C_{0}$ と負荷抵抗 $R_{0}$ 一供給する. 一方， $Q_{1}$ がオフすると $\mathrm{Q}_{2}$ の逆並列接続ダイオードがオンし, 同時にダイオード $\mathrm{D}_{2}$ がオン してフライバックコンバータとして働く. $\mathrm{Q}_{1}$ のオフ時, コンデン サC $(33 \mathrm{nF})$ は定常的な回路動作によって $\mathrm{Q}_{2}$ のドレイン側を正に 直流充電されており， $V_{\mathrm{i}}$ に $C$ の電圧を加えたものが $\mathrm{Q}_{1}$ オフ時の クランプ電圧となる. $\mathrm{Q}_{2}$ の逆並列接続ダイオードのオン期間中に トランスの励磁電流の一部が $C$ に流れ込んで $C$ の電圧が上昇し, その充電電圧がピークを迎えると，既にオンゲート信号を受けて いる $\mathrm{Q}_{2}$ を介して $C$ からの放電が行われる. この放電期間中に $C$ の 過充電された静電エネルギーの一部もダイオード $\mathrm{D}_{2}$ を介して $C_{\mathrm{o}}$ と $R_{0}$ 一供給される. $\mathrm{Q}_{2}$ がオフすると $\mathrm{Q}_{1}$ の逆並列接続ダイオード がオンし，トランスの励磁エネルギーの一部が $V_{\mathrm{i}}$ へ回生される.

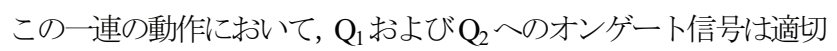
なデッドタイムを設けた上で, 自身の逆並列ダイオードの通流期 間中に与えられるので, FET のターンオン損失が極めて小さい ZVS が実現されている. また, $\mathrm{Q}_{1}$ または $\mathrm{Q}_{2}$ のオフ時に $V_{\mathrm{i}}-C$ の経 路がクランプ回路として働くので，これらのドレイン・ソース間 


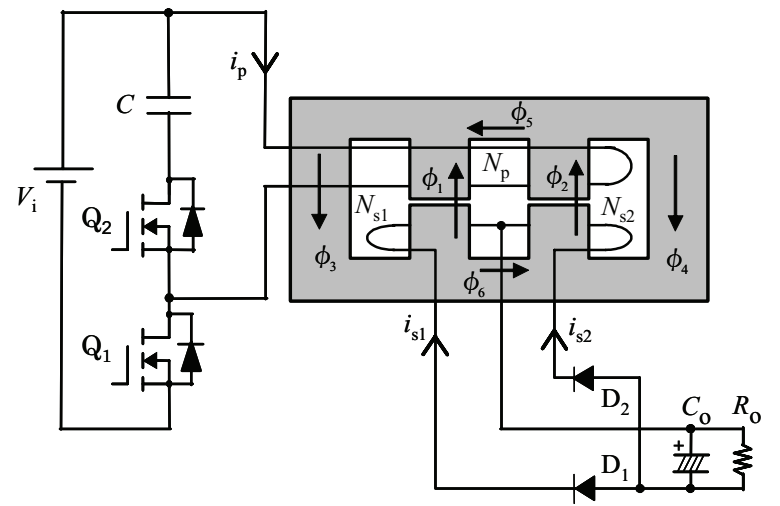

Fig. 2 Transformer with DCL.

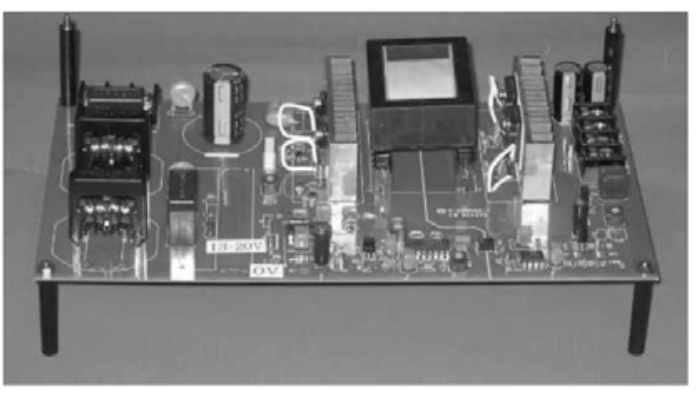

Fig. 3 Photograph of the DC-DC converter.

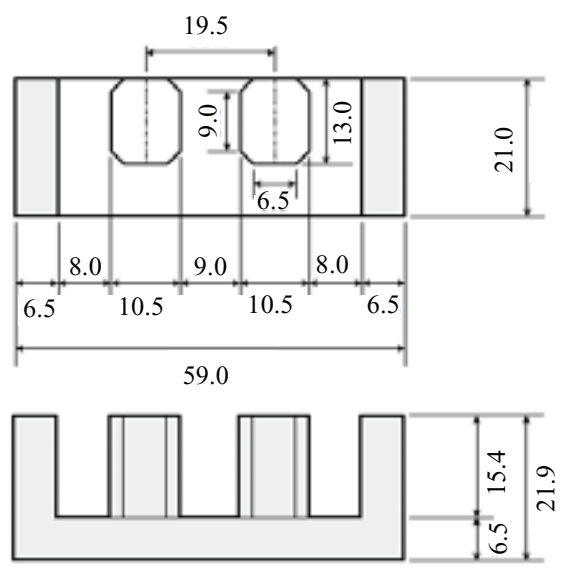

Fig. 4 Core dimensions (in $\mathrm{mm}$ ).

にターンオフ時の過大な跳ね上がり電圧は発生しない.

\section{2. $2 \mathrm{DCL}$ 機能付トランスを適用したコンバータ}

前節では $\mathrm{Q}_{1}$ のドレイン電流を制限するための DCL について触 れなかったが，試作コンバータには Fig.2 に示すような DCL 機能 付トランスを適用している. $\mathrm{Q}_{1}$ のオン時には $\mathrm{D}_{2}$ がオフしているの で，1次巻線 $N_{\mathrm{p}}$ に鎖交している 2 つトランス脚のうちの右側の 脚は主にリアクトルの磁心として働き，すなわち $\mathrm{Q}_{1}$ と直列接続さ れた DCL となる.この DCL 機能により $\mathrm{Q}_{1}$ オン時のドレイン電流 の值が制限され，この素子を過電流から保護している.

試作したコンバータの写真を Fig.3 に示す．定格出力電圧は $\mathrm{DC} 24 \mathrm{~V}$ であり, 負荷変動（定格出力 $150 \mathrm{~W}$ ）および入力電圧変動

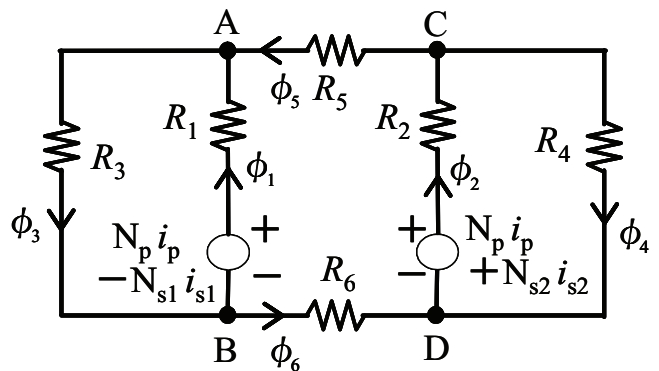

Fig. 5 Magnetic circuit of the transformer.

（DC100V〜200V）に対して出力電圧を定格值に保つように $\mathrm{Q}_{1}$ お よび $\mathrm{Q}_{2}$ のゲート信号を制御している. トランスの磁心寸法を Fig.4 に示す. トランスは Fig.4の磁心 2 つよって構成され, 1次巻線 および $2 つ の ~ 2$ 次巻線に鎖交する 2 つ脚にはそれぞれに数百 $\mu$ $\mathrm{m}$ 程度のエアギャップが設けてある. また，各巻線の巻数は，そ れぞれ $N_{\mathrm{p}}=14, N_{\mathrm{s} 1}=7$ および $N_{\mathrm{s} 2}=7$ である.

\section{3. 回路シミュレーションモデルの導出}

\section{1 研究課題}

本研究の課題は, コンバータ仕様を基に DCL のインダクタンス 值も含めて設計した回路に対し，回路シミュレーションによりト ランスの各巻線電流波形を把握してトランスの各脚の磁束を求め, 磁心寸法を含めたトランス設計のアルゴリズム開発に寄与するこ とである.

Fig.2 に示したトランスの磁気回路を Fig.5 に示寸. Fig.2 に示し た磁束 $\phi_{1} \sim \phi_{6}$ が通る磁路に対して Fig.5 に示した磁気抵抗 $R_{1} \sim R_{6}$ がそれぞれ対応している. 本研究の課題の遂行には，コンバータ 回路と Fig.5 の磁気回路を連立してシミュレーションすることが必 要であるが，磁気回路を解く上での入力は，回路シミュレーショ ン結果である巻線電流により算出される起磁力であり, 巻線電流 算出には, 磁気回路の解である磁束の時間変化率が必要である. この種の問題に対しては, 仮の初期值を決めて行う反復法などが 考えられるが, 収束性の吟味および解精度の検証の手間を考える と，より直接的に両回路の解を求める手法が望まれる.

本論文では，磁気回路と等価なトランスの励磁回路（電気回路） を導出して電気回路のみでコンバータ回路のシミュレーションを 実施する手法を提案し, 実験值との比較からその有効性を示す.

\section{2 磁気回路から電気回路への等価変換}

Fig.5 の磁気回路の磁束 $\phi_{1} \sim \phi_{6}$ に対し, 節点 $\mathrm{A} \sim \mathrm{D}$ における磁 束の連続性より

$$
\begin{aligned}
& \text { A : } \quad \phi_{1}=\phi_{3}-\phi_{5} \\
& \text { B : } \phi_{1}=\phi_{3}-\phi_{6} \\
& \mathrm{C}: \phi_{2}=\phi_{4}+\phi_{5} \\
& \mathrm{D}: \phi_{2}=\phi_{4}+\phi_{6}
\end{aligned}
$$

を得る. また，これらの両辺を時間微分すると

$$
\begin{aligned}
& \mathrm{d} \phi_{1} / \mathrm{d} t=\mathrm{d} \phi_{3} / \mathrm{d} t-\mathrm{d} \phi_{5} / \mathrm{d} t \\
& \mathrm{~d} \phi_{1} / \mathrm{d} t=\mathrm{d} \phi_{3} / \mathrm{d} t-\mathrm{d} \phi_{6} / \mathrm{d} t \\
& \mathrm{~d} \phi_{2} / \mathrm{d} t=\mathrm{d} \phi_{4} / \mathrm{d} t+\mathrm{d} \phi_{5} / \mathrm{d} t \\
& \mathrm{~d} \phi_{2} / \mathrm{d} t=\mathrm{d} \phi_{4} / \mathrm{d} t+\mathrm{d} \phi_{6} / \mathrm{d} t
\end{aligned}
$$




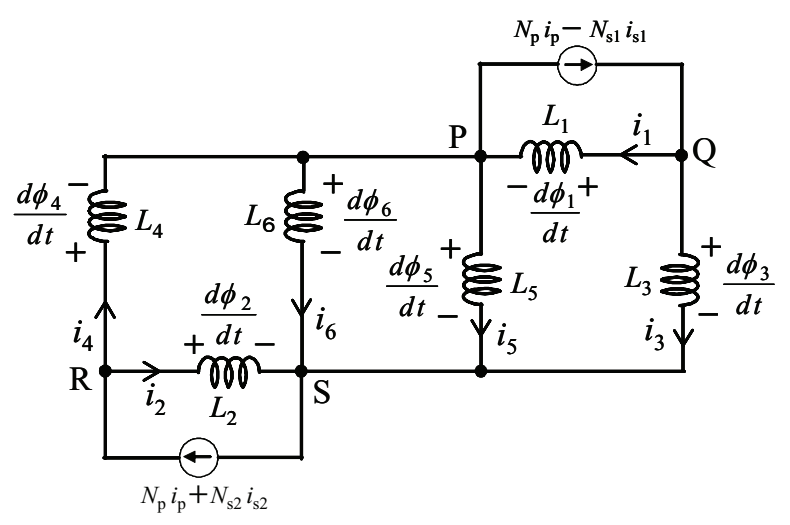

Fig. 6 Exciting circuit of the transformer.

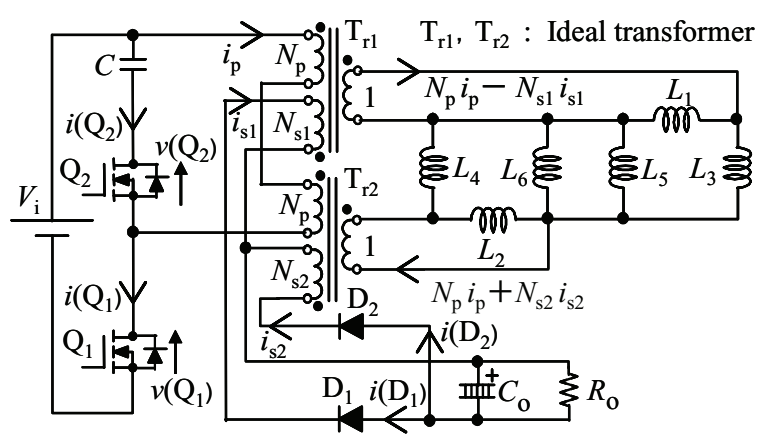

Fig. 7 Simulation circuit.

を得る. (2)式および Fig.5 に示した各巻線の起磁力より, Fig.6 の 電気回路を得る. ここで，各インダクタンスはFig.5 に示したトラ ンスの各脚の磁気抵抗の逆数で,

$$
\begin{aligned}
& L_{1}=1 / R_{1} \\
& L_{2}=1 / R_{2} \\
& L_{3}=1 / R_{3} \\
& L_{4}=1 / R_{4} \\
& L_{5}=1 / R_{5} \\
& L_{6}=1 / R_{6}
\end{aligned}
$$

となり, これらのインダクタンスの仮想巻数は寸べて 1 と考える. Fig.6の節点 Q におけるキルヒホッフの電流則より次式を得る.

$$
N_{\mathrm{p}} i_{\mathrm{p}}-N_{\mathrm{s} 1} i_{\mathrm{s} 1}=i_{1}+i_{3}
$$

但し, $N_{\mathrm{s} 1}$ は Fig.2 $2 \mathrm{D}_{1}$ と直列に接続された巻線の巻数であり, $i_{\mathrm{p}}$, $i_{\mathrm{s} 1}, i_{1}$ および $i_{3}$ はそれぞれ $N_{\mathrm{p}}, N_{\mathrm{s} 1}, L_{1}$ および $L_{3}$ に流れる電流であ る. ここで，仮想的な電流 $i_{1}$ によって実際の磁束 $\phi_{1}$ が生ずると考 え, $L_{1} i_{1}=\phi_{1}$ とし, 同様にして, $L_{3} i_{3}=\phi_{3}$ とすると, (3)式より

$$
N_{\mathrm{p}} i_{\mathrm{p}}-N_{\mathrm{s} 1} i_{\mathrm{s} 1}=R_{1} \phi_{1}+R_{3} \phi_{3}
$$

を得，これは Fig.5 の磁路 A-B-A の起磁力方程式と一致している.

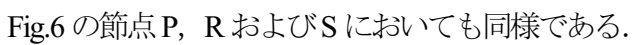

Fig.2 のトランス部を Fig.6 に置き換えると回路シミュレーショ ンモデル Fig.7が導出される.ここでは，トランスの巻線間の磁気 結合を $2 つ の$ 理想変圧器を用いてこれと等価な電気結合に変換し ている. この電気結合は，2つの理想変圧器にそれぞれ巻数 1 の 第3の巻線を仮定し，この巻線間にインダクタンスからなる等価 励磁回路を接続することで害現している.
Table 1 Inductances $(\mu \mathrm{H})$.

\begin{tabular}{|l|l|l|l|l|l|}
\hline$L_{1}$ & $L_{2}$ & $L_{3}$ & $L_{4}$ & $L_{5}$ & $L_{6}$ \\
\hline \multicolumn{2}{|c|}{0.52} & \multicolumn{2}{|c|}{9.3} & \multicolumn{2}{|c|}{43} \\
\hline
\end{tabular}

Fig.7 において $\mathrm{Q}_{1}$ がオンしている期間，2つの理想変圧器に直列 に共通して流れる 1 次巻線電流 $i_{\mathrm{p}}$ が発生するが，この時，理想変 圧器 $\operatorname{Tr}_{1}$ では $N_{\mathrm{sl}}$ にフォワードコンバータとしての出力電流が負荷 一流れる一方, 1 回巻の 3 次巻線には負荷への出力電圧を $N_{\mathrm{s} 1}$ で割 った值の電圧が等価励磁回路にかかり, 励磁電流 $N_{\mathrm{p}} i_{\mathrm{p}}-N_{\mathrm{s} 1} i_{\mathrm{s} 1}$ がこ の 3 次巻線に流れる. 一方, 理想変圧器 $\mathrm{Tr}_{2}$ では, $\mathrm{D}_{2}$ がオフしてい るので $N_{\mathrm{s} 2}$ には電流が流れないが, $\operatorname{Tr}_{2}$ の 3 次巻線に $N_{\mathrm{p}} i_{\mathrm{p}}$ が流れる. $\mathrm{Tr}_{2}$ の 3 次巻線に接続されている等価励磁回路には直流成分を含ん だ電流が継続して流れDCL として働いており, $\mathrm{Q}_{1}$ オン時のドレイ ン電流波高值の制限をこの回路で行っている。

Fig.7において $\mathrm{Q}_{1}$ がオフすると $\mathrm{Q}_{2}$ の逆並列ダイオードがオンし， $\operatorname{Tr}_{1}$ の $N_{\mathrm{p}}$ の電圧極性の反転に伴い $N_{\mathrm{s} 1}$ の電圧極性も反転し, $\mathrm{D}_{1}$ が才 フ寸る. $\operatorname{Tr}_{1}$ の3 次巻線側の等価厉磁回路に流れている電流の連続 性から $\operatorname{Tr}_{1}$ の $N_{\mathrm{p}}$ には継続して電流が流れ, $C$ を過充電する. 一方, $\operatorname{Tr}_{2}$ では，3次巻線に接続された等価励磁回路のエネルギーがフラ イバックコンバータとして $\mathrm{D}_{2}$ を介して負荷へ供給されると同時に, このエネルギーの一部は， $C$ の過充電一寄与する. やがて $C$ への 充電が終了して放電状態になると, オン状態の $\mathrm{Q}_{2}$ を介し, この放 電エネルギーの一部は $\operatorname{Tr}_{2}$ の $N_{\mathrm{p}}$ から $N_{\mathrm{s} 2}$ に向けて放出される形で負 荷へ出力される. このとき, $\operatorname{Tr}_{1}$ の 3 次巻線電流の向きは反転し, この巻線には交流電流成分のみが生ずる.

以上のように, Fig.2 ではトランスの磁気結合が回路動作一与え る影響を把握することは容易ではなかったが，Fig.7 を用いること で, ZVS を実現した DCL 機能を含むフォワードコンバータ動作お よびフライバックコンバータ動作を把握することができた。

\section{3 回路シミュレーションの履行}

Fig.5 の磁気抵抗 $R_{1} \sim R_{6}$ は, 磁心が Fig.4 に示したような形状で あるので, $R_{1}$ と $R_{2}$ の脚は実際と磁路断面積が等しい長方形断面と した. また, これらの3 次元形状の磁気抵抗の值の算出は, 文献 2)記載の方法を適用した. ここで, 磁心材質は JFE フェライト製 MBT1 であり比透磁率はその $23^{\circ} \mathrm{C}$ におけるカタログ值 3400 を用い た. また, エアギャップ幅は, 実際に印加した巻線電圧と電流の 時間変化率から逆算した值 $(300 \mu \mathrm{m})$ を用いた. これらにより求 めた Fig.6のインダクタンス $L_{1} \sim L_{6}$ の值を Table 1 に示す.

Fig.7 の回路のシミュレーションには Spice 系の回路シミュレー タ SIMetrix 妾を用いた. また, 制御系を含めたシミュレーションは 行わず,シミュレーションにおける $\mathrm{Q}_{1}$ および $\mathrm{Q}_{2}$ のオン時間幅は, $V_{\mathrm{i}}=100 \mathrm{~V}$ として, 概ね定格負荷となる $R_{0}=4.2 \Omega$ を接続した時 の実機の值とした.

\section{4. シミュレーション結果の検証}

SIMetrix は過渡現象を扱うシミュレータであるので, シミュレー ション上の過渡現象が概ね終了した後の各波形について, 実機の 測定波形と比較する. 


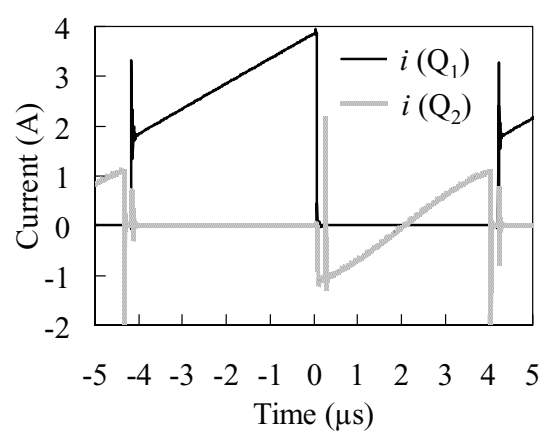

(a) Simulated.

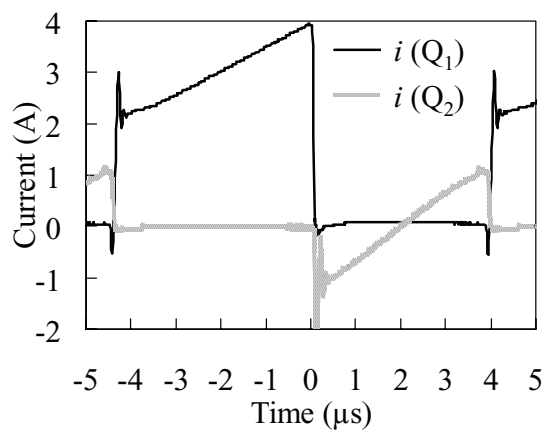

(b) Measured.

Fig. 8 Current waveforms of $i\left(\mathrm{Q}_{1}\right)$ and $i\left(\mathrm{Q}_{2}\right)$.

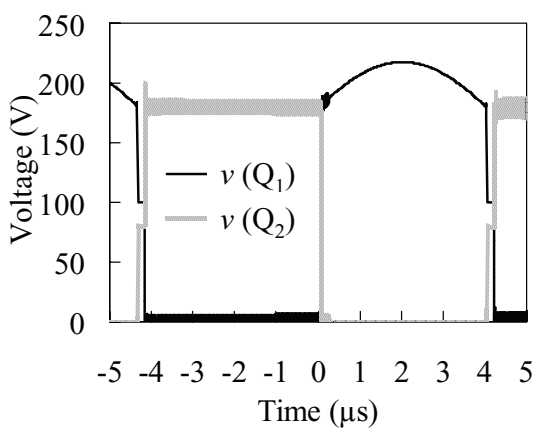

(a) Simulated.

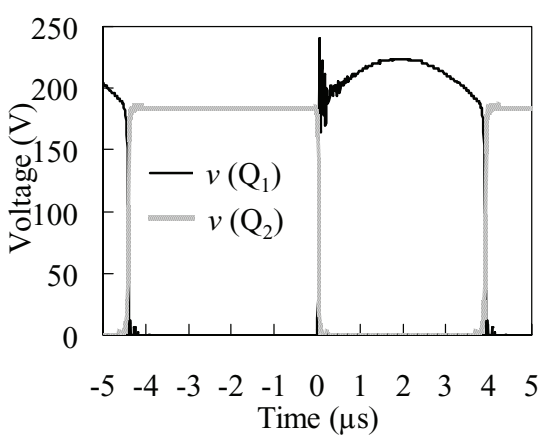

(b) Measured.

Fig. 9 Voltage waveforms of $v\left(\mathrm{Q}_{1}\right)$ and $v\left(\mathrm{Q}_{2}\right)$.

$\mathrm{Q}_{1}$ および $\mathrm{Q}_{2}$ またはこれらの逆並列ダイオードに流れる電流を Fig.8 に示寸. ここで，(a)および(b)は，それぞれシミュレーショ ンおよび実験による結果を示しており，Fig.9 および Fig.10 にお

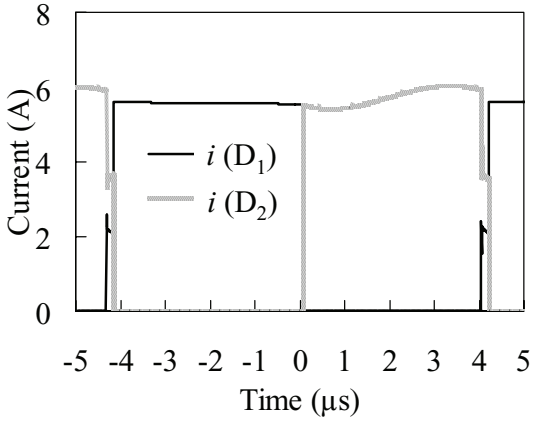

(a) Simulated.

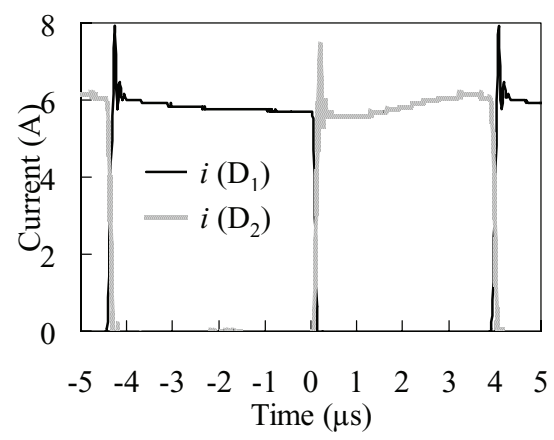

(b) Measured.

Fig. 10 Current waveforms of $i\left(\mathrm{D}_{1}\right)$ and $i\left(\mathrm{D}_{2}\right)$.

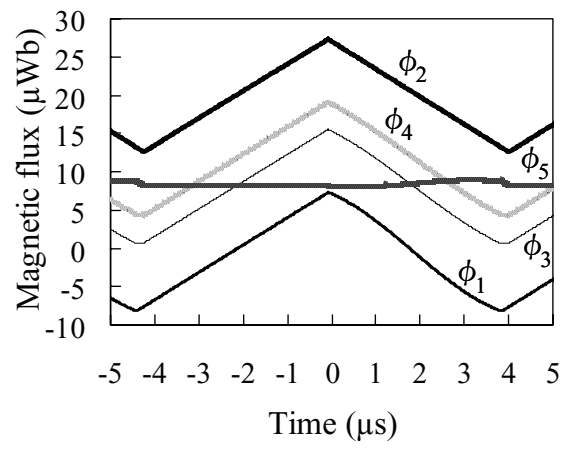

Fig. 11 Simulated magnetic flux waveforms of $\phi_{1^{-}} \phi_{5}$.

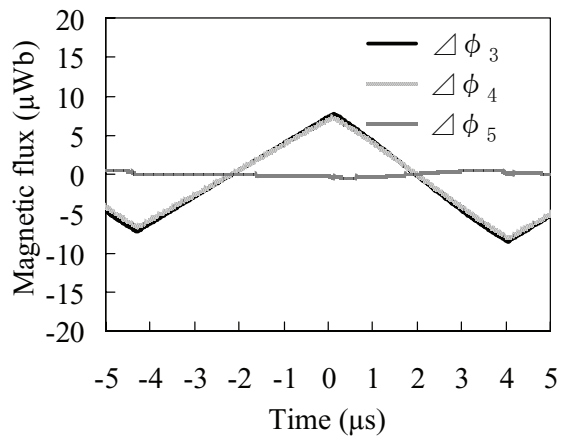

Fig. 12 Measured magnetic flux waveforms of $\phi_{3}{ }^{-} \phi_{5}$ without DC components.

いても同様である. $\mathrm{Q}_{1}$ および $\mathrm{Q}_{2}$ のドレイン・ソース間電圧を Fig.9 
に示す. トランス 2 次側に接続されている $\mathrm{D}_{1}$ および $\mathrm{D}_{2}$ の電流を Fig.10 に示す. Fig.8 〜Fig.10 の(a)および(b)は概ね一致しており, また, 直流出力電圧のシミュレーション值も $24 \mathrm{~V}$ で実験值と等し く, 提案したシミュレーションモデルの妥当性が示された.

回路シミュレーションで得られたトランスの各巻線 $N_{\mathrm{p}}$, $N_{\mathrm{s} 1}$ および $N_{\mathrm{s} 2}$ の電流 $i_{\mathrm{p}}, i_{\mathrm{s} 1}$ および $i_{\mathrm{s} 2}$ を用いて Fig.5 に示した $\phi_{1} \sim \phi_{5}$ を求めた結果を Fig.11に示す.ここで， $\phi_{6}$ は $\phi_{5}$ に 等しい. この結果から DCL 機能を担う直流磁束は $\phi_{2}$ であ ることが分かるが,この磁束の閉ループとしては, $\phi_{4}$ に加え

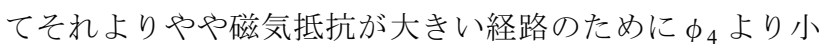
さい $\phi_{5}-\phi_{3}-\phi_{6}$ のループがあることが分かる. 一方， $\phi_{1}$ に は直流磁束成分はないことが分かる. 実験では直流磁束の 計測はできないが，交流磁束成分はサーチコイルをトラン スの脚に巻くことで計測できるので, 励磁巻線を施してい ない脚に 3 回巻のサーチコイルをそれぞれ施し, 磁束 $\phi_{3} \sim$ $\phi_{5}$ の交流分を計測した結果を Fig.12 に示す. Fig.11 に示 した $\phi_{3} \sim \phi_{5}$ の交流成分は Fig. 12 と概ね一致し, 各磁束の 算出結果の妥当性を支持している.

Fig.11で最も大きい值を取る $\phi_{2}$ の波高值は, 磁束密度に 換算すると $210 \mathrm{mT}$ である。 よって, トランス脚内の磁束 は非飽和領域にあり, 今回の励磁条件においては, 脚から の漏れ磁束を無視して扱った Fig.5 の磁気回路による解析 は有効である。また, 各巻線に流れる電流のシミュレーシ ヨン值と実験值との比較結果から, 各巻線電流を定量的に シミュレーションできたことが分かり, 直流分を含む起磁 力 $N_{\mathrm{p}} i_{\mathrm{p}}+N_{\mathrm{s} 2} i_{\mathrm{s} 2}$ による直流分を含んだ各磁束の值の妥当性 が保証されている.

最後に一点, 考察を述べる. シミュレーションでは Fig.6 の $L_{1} \sim L_{6}$ に流れる電流を求めており, これらより直接 $\phi_{1} \sim \phi_{6}$ を計算することはできるが,この方法により求めた $\phi_{1} \sim \phi_{6}$
は Fig.5 の節点における磁束の連続性を満足しなかった. これは, Fig.6 は(2)式より導出されたもので, 磁束の時間 変化率を拘束, 寸なわち Fig.6 の $L_{1} \sim L_{6}$ にそれぞれかかる 電圧を回路解析条件としているが, Fig.6の $L_{1} \sim L_{6}$ から成る すべての閉ループに関してどのような直流電流が流れてい ても 2 つ電流源の值を満足する解は無数にあることにな り，この方法では直流磁束の実態を得ることはできなかっ た.

\section{5. 結 言}

DCL 機能を有したトランスを適用した DC-DC コンバー タにおいて, トランスの各巻線間の磁気結合と等価な電気 回路を導出し, 実機と整合性のある回路シミュレーション を実現した。この等価電気回路では，2つの理想変圧器そ れぞれに巻数 1 回の 3 次巻線を設け, トランスの各脚の磁 気抵抗に対応したインダクタンスから成る回路を介してこ れらの 3 次巻線を電気結合させてトランス全体の励磁回路 を形成し，各巻線間の磁気結合を扱った。

本手法により, DCL 機能付トランスの各脚の直流磁束を 含めた磁束分布が明らかとなり, その解析結果をトランス 磁心の寸法設計等に活用することで, 低コスト化が要求さ れるこの種の DC-DC コンバータの設計精度向上が期待で きる.

\section{References}

1) H.Unno,Y.Matsuda, and H.Watanabe : "Input and Output Choke-less BHB Converter", IEICE Sougou Taikai SB-6-3(2003).

2) Y. Saito: Comp. Meths. Appl. Mech. Eng., 22289 (1980). 3) http://www.catena.uk.com/

2006 年 10 月 2 日受理, 2007 年 1 月 23 日採録 